\title{
Form IA rbcL transcripts associated with a low salinity/high chlorophyll plume ('Green River') in the eastern Gulf of Mexico
}

\author{
John H. Paul ${ }^{1, *}$, Albin Alfreider ${ }^{2}$, Jordan B. Kang ${ }^{1}$, Roger A. Stokes ${ }^{1}$, Dale Griffin ${ }^{1}$, \\ Lisa Campbell ${ }^{3}$, Erla Ornolfsdottir ${ }^{3}$ \\ 'Department of Marine Science, University of South Florida, 140 Seventh Avenue South St. Petersburg, Florida 33701, USA \\ ${ }^{2}$ Institute of Zoology and Limnology, University of Innsbruck, Technikerstrasse 25, 6020 Innsbruck, Austria \\ ${ }^{3}$ Department of Oceanography, Texas A\&M University, College Station, Texas 77843-3146, USA
}

\begin{abstract}
Coastal plumes of low salinity water that extend hundreds of kilometers offshore into oligotrophic waters are often found in the Gulf of Mexico. To characterize one such feature, a series of photoautotrophic activity and biomass parameters were measured at 2 stations in the eastern Gulf of Mexico, including pigments by high performance liquid chromatography (HPLC), autotrophic picoplankton abundance by flow cytometry, photoautotrophic ${ }^{14} \mathrm{C}-\mathrm{HCO}_{3}^{-}$fixation, and Ribulose-1,5diphosphate carboxylase large subunit gene $(r b c L)$ transcriptional activity. One sampling site (Stn 4) was in a $15 \mathrm{~m}$ deep, low salinity (29.8 ppt) plume $242 \mathrm{~km}$ west of Tampa Bay. This feature contained relatively high chlorophyll a ( $\mathrm{chl}$ a) concentrations, carbon fixation rates, and Synechococcus cell abundance $\left(8.6 \times 10^{4}\right.$ cells $\left.\mathrm{ml}^{-1}\right)$ at $3 \mathrm{~m}$ depth and a relatively shallow (45 $\mathrm{m}$ depth) subsurface chlorophyll a maximum (SCM). We also found a high level $\left(1.1 \mathrm{ng} \mathrm{l}^{-1}\right)$ of Form IA rbcL mRNA in the surface water as determined by probing with a $1.1 \mathrm{~kb}$ Synechococcus WH7803 rbcL probe. Form $1 \mathrm{~A}$ rbcLs have been found to occur mainly in chemosynthetic autotrophic bacteria but have recently been described in Synechococcus WH7803 as well as in Prochlorococcus GP2. In contrast, a nearby station outside of the plume (Stn 7) had a SCM at $83 \mathrm{~m}$, lower $\mathrm{chl} a_{1}$ Synechococcus cell counts, and carbon fixation rates in the surface waters. The amount of Form IA $r b c L$ was only about $3 \%$ of the concentration found in the surface waters of Stn 4 . Both stations had an abundance of Prochlorococcus cells $\left(>10^{5} \mathrm{ml}^{-1}\right)$ at intermediate depths $(20$ to $70 \mathrm{~m})$. The picoeucaryote community occurred principally below the Prochlorococcus community, coinciding with the SCM, and was composed of diatoms, prymnesiophytes, and pelagophytes as determined by HPLC pigment analysis. This report represents the first description of Form IA $r b c L$ transcriptional activity in the marine environment, and indicates that Form $1 \mathrm{~A} r b c L$ containing picoplankton (like Prochlorococcus GP2 and Synechococcus WH7803) may be important in the primary production of low salinity, surface water plumes of the Gulf of Mexico.
\end{abstract}

KEY WORDS: RuBisCO · Gene expression · Phytoplankton · Gulf of Mexico

\section{INTRODUCTION}

The oceans are now known to be environments of abundant microbial diversity, in both the autotrophic and heterotrophic components of microbial assemblages (Giovanonni et al. 1990, DeLong 1992, Fuhrman et al. 1992, 1993). The photoautotrophic community in oligotrophic environments has been shown to be domi-

\footnotetext{
•E-mail: jpaul@seas.marine.usf.edu
}

nated by the picoplankton, which include the cyanobacteria Synechococcus and Prochlorococcus, and small eucaryotic algae (picoeucaryotes). These groups have been shown to occupy their own respective niches in space and time (Stockner 1988, Landry et al. 1996, Campbell et al. 1997). In stratified water columns, the abundance maxima for each of these 3 major picoplanktonic groups are often vertically separated, yet the order of these groups varies with the environment sampled (Campbell et al. 1997, Paul et al. 1999). 
Although Synechococcus has been termed a provisional taxonomic division which has been subdivided into 6 groups (Waterbury \& Rippka 1989), analysis of several loci suggest a high degree of diversity even in the marine picoplanktonic strains (Urbach et al. 1998). For example, examination of the RNA polymerase genes (rpo loci) has indicated the existence of 2 major groups amongst 15 isolates and 3 minor groups within 1 major group (Toledo \& Palenik 1997). Similarly, 2 deeply rooted branches of Synechococcus emerged upon study of the petB, petD, and $p s b B$ sequences (Urbach et al. 1998). Prochlorococcus, which was previously viewed as a homogeneous group (Chisholm et al. 1988, 1992), is now known to be an equally diverse group (Scanlan et al. 1996, Ferris \& Palenik 1998, Moore et al. 1998, Urbach \& Chisholm 1998).

Over the years, we have been interested in the molecular regulation of photosynthetic cärbon fixation, focusing on the picoplankton (Pichard et al. 1993, $1997 a, b$, Paul et al. 1999). Ribulose-1,5-diphosphate carboxylase/oxygenase (RuBisCO) is believed to be responsible for $95 \%$ of the carbon fixation in oceanic phytoplankton (Raven 1995). Our approach to this problem has been to investigate the transcriptional regulation of the gene for the large subunit of RuBisCO, rbcL: Although there is some conservation in sequence, the diversity of this gene enables its use for identification of taxa (Paul et al. 2000, in this issue). There are 3 major evolutionary divisions in this gene which encode for Form I, Form II, and Form III/IV RuBisCOs (Tabita 1988, Watson \& Tabita 1996, 1999). The primary type found in oceanic phytoplankton and land plants is the Form I. Form II is found in several photosynthetic bacteria and some dinoflagellates (Morse et al. 1995) and a third and fourth form have recently been described in Archaea, although no active enzyme has been found in these (Watson \& Tabita 1999).

The important phytoplankton clades of the Form I enzyme include Form IB, which encompasses cyanobacteria and green algae, and Form ID, which is found in diatoms, prymnesiophytes, cryptophytes, pelagophytes, brown and red algae (Douglas et al. 1990, Newman \& Cattocolico 1990, Valentin \& Zetsche 1990, Hwang \& Tabita 1991, Watson \& Tabita 1997). We have previously used gene probes derived from partial transcripts from both a Form IB and a Form ID $\mathrm{RuBisCO}$ as a means to measure transcriptional regulation of RuBisCO in oceanic phytoplankton (Pichard et al. 1997a). We have demonstrated a temporal and spatial separation in the expression of Form IB and ID $r b c L s$, with Form IB occurring in the upper water column and coincident with Synechococcus abundance maxima, and Form ID primarily at the subsurface chlorophyll a maximum (SCM), correlating with picoeucaryote counts (Paul et al. 1999).
Recently, rbcL sequences from Synechococcus WH7803 and Prochlorococcus GP2 have placed these organisms in the Form IA group, thought to contain only $\beta$ - and $\gamma$-purple (chemosynthetic sulfur oxidizing and other) bacteria (Watson \& Tabita 1996). In this report we have employed a Form IA $r b c L$ gene probe derived from Synechococcus WH7803 to determine if transcriptional activity was occurring from this group of organisms in the Gulf of Mexico.

\section{MATERIALS AND METHODS}

Sampling sites. Sampling was performed aboard the RV 'Pelican' in the SE Gulf of Mexico (see Fig. 1A) on 14 August 1997 (Stn 4) and 10 August 1997 (Stn 7). Sampling was performed using a rosette of Niskin bottles attached to a Seabird CTD between 08:00 and 10:00 h each day. Samples from depths greater than $40 \mathrm{~m}$ were protected from light by wrapping carboys in black plastic garbage bags.

rbcL mRNA analysis. Samples for mRNA analysis (usually 500 to $800 \mathrm{ml}$ ) were treated with $0.1 \%$ (final concentration) diethylpyrocarbonate (DEPC $i$ Sigma Chemical Corp.) immediately prior to filtration through $25 \mathrm{~mm}, 0.45 \mu \mathrm{m}$ polyvinylidene difluoride filters (Millipore Durapore). Use of the $0.22 \mu \mathrm{m}$ pore-sized filters resulted in no recovery of RNA from the samples. Filters were added to $2.2 \mathrm{ml}$ bead-beater tubes (Microspecs, Bartlesville, OK) containing guanidinium isothiocyanate extraction reagent (Pichard et al. 1993), immediately frozen in liquid nitrogen, and stored at $-80^{\circ} \mathrm{C}$ until extraction (within $1 \mathrm{mo}$ of sampling). RNA was extracted by bead-beating, followed by dotblotting and molecular probing (Pichard et al. 1993, 1997 a). This process has been shown to result in $\sim 80 \%$ recovery of cellular RNA (Pichard et al. 1993). Duplicate samples were probed with the Form IB and Form ID probes derived from Synechococcus PCC6301 and Cylindrotheca sp. N1 as previously described (Pichard et al. 1997a). A third set of duplicate samples was probed with a Form IA probe derived from Synechococcus WH7803 (Watson \& Tabita 1996). This probe was constructed by subcloning an $1196 \mathrm{Sal} / \mathrm{Sac}$ restriction fragment of the Synechococcus WH7803 rbcL gene into the pGEM3Z vector (Promega, Madison, WI). Radiolabeled probes were made by in vitro transcription of the genes using ${ }^{35} \mathrm{~S}$-UTP. Dot blots were quantitated with a BioRad Model GS363 Molecular Imager using standard curves made from $r b c L$ genes from Synechococcus PCC6301, Cylindrotheca sp N1, and Synechococcus WH7803.

Flow cytometry. One $\mathrm{ml}$ samples were fixed with $20 \mathrm{\mu l} 10 \%$ paraformaldehyde at room temperature for $10 \mathrm{~min}$ and quickly frozen in liquid nitrogen. Prochloro- 
coccus, Synechococcus, and picoeucaryotic algal populations were quantified using a Becton Dickinson FACSCalibur (San Jose, CA) Flow cytometer equipped with a $488 \mathrm{~nm}, 15 \mathrm{~mW}$ Argon laser. Forward angle light scatter, right angle light scatter, green (530 \pm $30 \mathrm{~nm})$, orange $(585 \pm 30 \mathrm{~nm})$, and red $(650 \pm 30 \mathrm{~nm})$ fluorescence parameters were collected for each event. Purple-Yellow calibration beads $(2.2 \mu \mathrm{m}$, Spherotech Inc., IL) were added to each sample to permit normalization of all fluorescence signals. Data were collected using CellQuest ${ }^{\mathrm{TM}}$ software (Ver. 3, Becton Dickinson 1996), transferred to a personal computer (PC), and analyzed using CYTOWIN software (Vaulot 1989, http://www.sb-roscoff.fr/Phyto/cyto.html\#cytowin). Event rates were recorded for each sample as it was run and abundances were corrected for volume analyzed and an enumeration efficiency factor. The efficiency factor was derived from event rate and counts for a series of known concentrations of calibration beads.

HPLC pigment analysis. Two to $4 \mathrm{l}$ of sample water were filtered through $2.5 \mathrm{~cm}$ Whatman GF/F glass fiber filters in duplicate. The filters were folded in half, wrapped in aluminum foil, frozen immediately in liquid nitrogen, and stored at $-80^{\circ} \mathrm{C}$. The filters were extracted with $100 \%$ acetone and extracts analyzed by (HPLC) by B. Pedersen, Mote Marine Lab, using the method of Millie et al. (1993).

Chlorophyll a analysis. Samples for chl a were collected by filtration onto $2.5 \mathrm{~cm}$ Whatman GF/F glass fiber filters in triplicate and stored frozen until extraction. Filters were extracted in methanol and the chl a determined fluorometrically (Holm-Hansen \& Riemann 1978).

${ }^{14} \mathrm{C}$-carbon fixation. ${ }^{14} \mathrm{C}$-carbon fixation studies were performed essentially as described in Pichard et al. (1993, 1997a) using sterile, acid-cleaned $500 \mathrm{ml}$ poly- carbonate flasks and $325 \mathrm{ml}$ water samples. On-deck incubations were performed with natural irradiance that was adjusted to resemble the intensity and spectral features of the underwater light field using neutral-density screening and colored acetate filters. Irradiance intensity as a function of depth was determined by use of a Li-Cor light meter equipped with Li-190SA and Li-192SA surface and underwater photosynthetically active radiation sensors.

\section{RESULTS}

At Stn 4 , the water column was highly stratified as indicated by the steep thermocline and the low salinity surface water (Fig. 1B). The surface water salinity was $-29 \mathrm{ppt}$ and increased to $36 \mathrm{ppt}$ at $25 \mathrm{~m}$, where it remained constant to the base of the euphotic zone. The in vivo fluorescence was highest in the low salinity 'lens' near the surface $(0$ to $10 \mathrm{~m})$. The SCM was relatively shallow $(45 \mathrm{~m})$ compared to other stations in this area and the depth of the $1 \%$ light intensity was approximately $60 \mathrm{~m}$ (Fig. 2A).

Photosynthetic carbon fixation showed a maximum in the surface waters (Fig. 2A) and decreased to $20 \mathrm{~m}$, remaining near constant to $60 \mathrm{~m}$ (through the SCM). Below $60 \mathrm{~m}$ carbon fixation decreased dramatically. $\mathrm{Chl}$ a followed the in vivo fluorescence with maxima at the surface and at the SCM $(45 \mathrm{~m})$.

Fig. 2B shows the flow cytometry data for Stn 4 . The highest numbers of Synechococcus occurred in the surface waters $\left(8.6 \times 10^{4}\right.$ cells ml $\left.{ }^{-1}\right)$ with a secondary

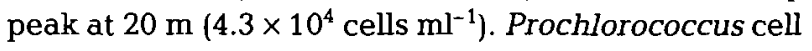
counts were undetectable in the surface waters but peaked at $40 \mathrm{~m}\left(1.4 \times 10^{5}\right.$ cells $\left.\mathrm{ml}^{-1}\right)$.

The picoeucaryote cell maximum $\left(2.3 \times 10^{3}\right.$ cells ml$\left.^{-1}\right)$ occurred below the Prochlorococcus population at the
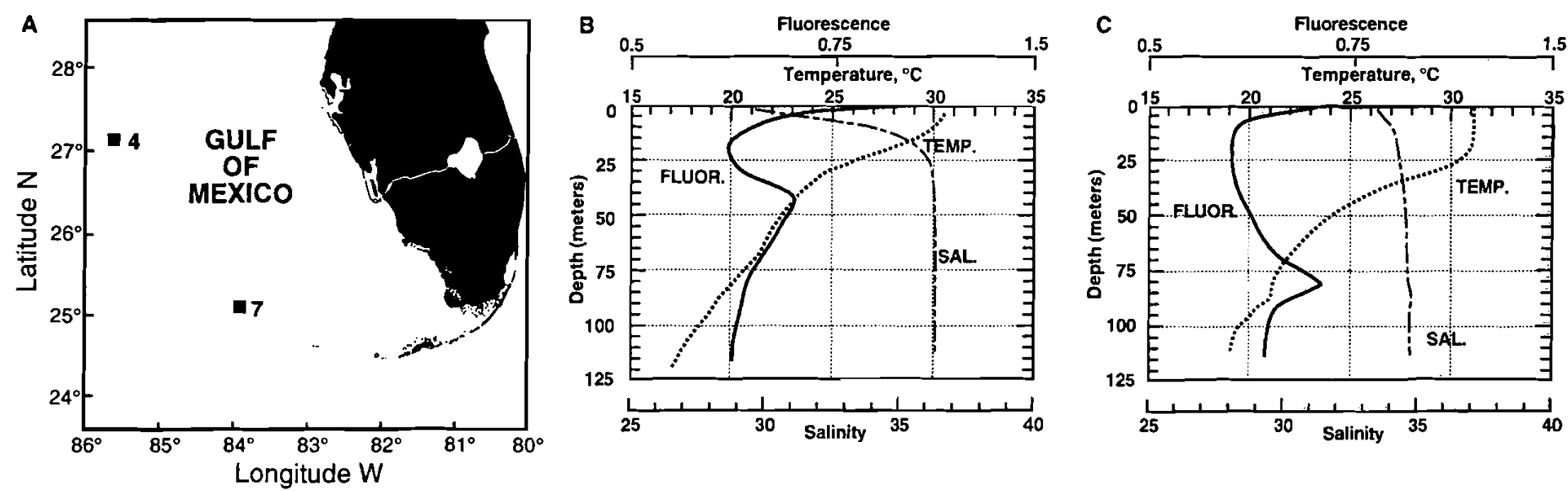

Fig. 1. (A) Location of stations sampled in this study. (B \& C) CTD traces for Stns 4 and 7, respectively. Notice the low salinity surface feature at $\operatorname{Stn} 4$ (B), and approximate position of the SCMs as indicated by in situ fluorescence trace (labeled 'FLUOR.') 

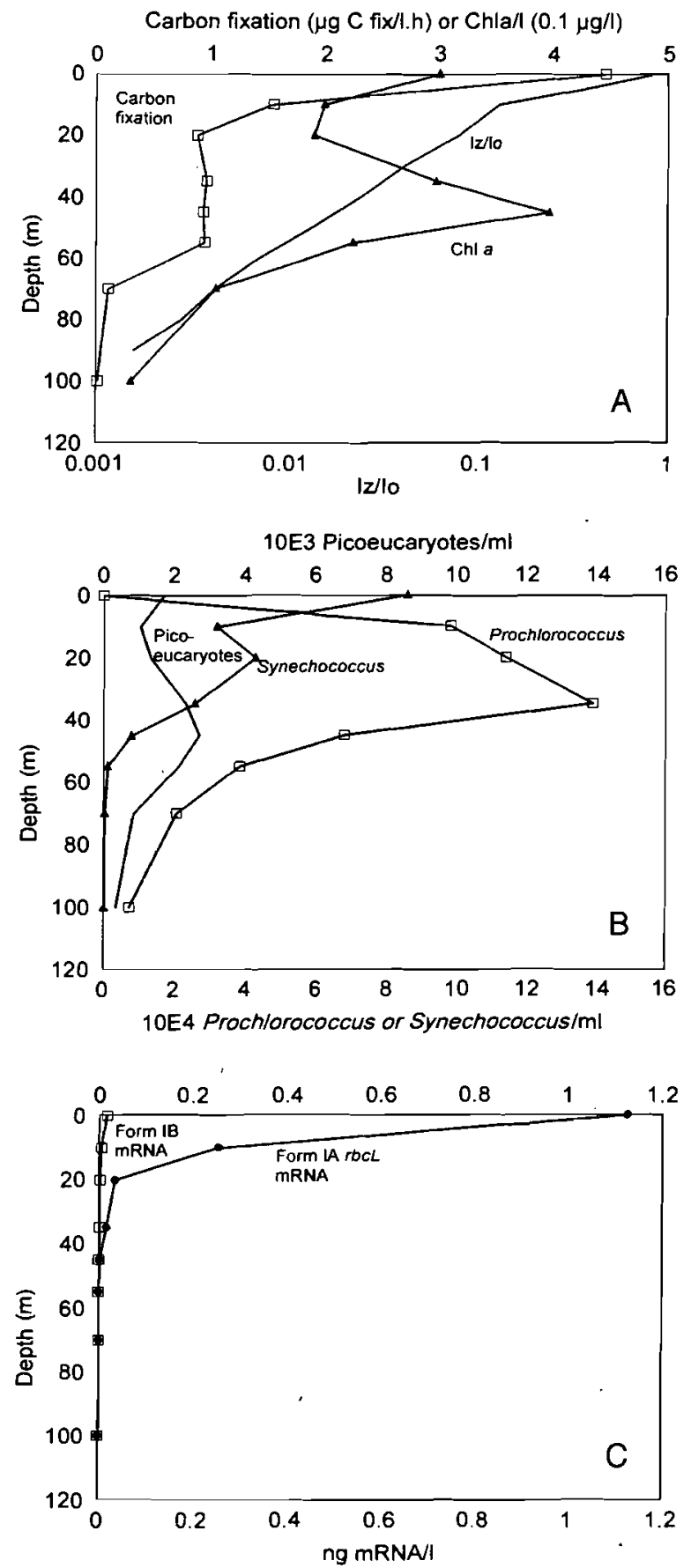

Fig. 2. (A) Relative light intensity (Iz/Io, - ), photosynthetic carbon fixation (Carbon fixation, ㄷ), and chl $a$ (chl $a, 4)$ at Stn 4. (B) Flow cytometry data from Stn 4, including Prochlorococcus (), Synechococcus (4), and picoeucaryote (-) cell abundance. (C) $r b c L$ mRNA levels for Stn 4, including Form IA $(\bullet)$ and Form IB (ㅁ)

SCM. Thus, these 3 picoplankton groups were vertically stratified, with the Synechococcus maximum at the surface, followed by Prochlorococcus at $40 \mathrm{~m}$, and the picoeucaryotes at the SCM.
Fig. 2C shows the distribution of $r b c L$ mRNA in the water column of Stn 4 . The greatest amount of Form IA $r b c L$ mRNA occurred in the surface waters, and rapidly decreased to undetectable levels at $45 \mathrm{~m}$. The Form IB $r b c L$ mRNA, an abundant form in the Gulf of Mexico (Pichard et al. 1997a, Paul et al. 1999), was also maximal in the surface waters but was approximately 70 -fold less abundant than the Form IA $r b c L$ mRNA. No Form ID $r b c L$ was found in these samples.

Fig. 3 displays the results of HPLC pigment analysis for the waters of Stn 4. Divinyl chl $a$ and divinyl chl $b$, diagnostic pigments for Prochlorococcus, were maximal at the SCM, with no detectable pigment levels in the surface waters. These data paralleled the flow cytometry data. Zeaxanthin, a pigment diagnostic for cyanobacteria, was highest in the surface waters, with a secondary peak occurring at $35 \mathrm{~m}$. Chl $c 1$ and $c 2$, components of all chromophytic algae, exhibited a peak in the surface waters and then a large peak at the SCM. Fucoxanthin, found in diatoms and prymnesiophytes, showed a peak at the surface and also at the SCM, mirroring the chl $c 1$ and $c 2$ data. Thus, the surface plume was comprised of chromophytic eucaryotes as well as Synechococcus. Both 19'-hexanoyl-oxyfucoxanthin, a pigment contained primarily in prymnesiophytes, and 19'-butanoyl-oxyfucoxanthin, a pigment found in pelagophytes, were maximal at the SCM.

Stn 7 was more typical of the oligotrophic Gulf of Mexico than Stn 4. The depth of the mixed layer was $\sim 25 \mathrm{~m}$, after which a steep thermocline occurred (Fig. 1C). Unlike Stn 4, the SCM occurred at approximately $83 \mathrm{~m}$. Salinity was relatively constant over the entire $110 \mathrm{~m}$ euphotic zone, ranging from 35.8 to $36.4 \mathrm{ppt}$.

Fig. 4A shows the distribution of carbon fixation, light intensity, and chl $a$ as a function of depth at $\operatorname{Stn} 7$. The depth at which illumination was $1 \%$ of that at the surface was approximately $80 \mathrm{~m}$, and coincided with the depth of the SCM. Unlike Stn 4, there was no dramatic maxima in carbon fixation or chl $a$ in the surface waters. The carbon fixation peak covered a broad expanse of depths, from 20 to $80 \mathrm{~m}$.

Fig. 4B shows the results of flow cytometry data for Stn 7. Prochlorococcus was the most numerically abundant picoplankter, with a maximal abundance of $1.83 \times$ $10^{5} \mathrm{cells} \mathrm{ml}^{-1}$ at the $50 \mathrm{~m}$ depth. As with Stn 4 , the Synechococcus peak was in the surface waters $(2.22 \times$ $10^{4}$ cells $\mathrm{ml}^{-1}$ ) and the picoeucaryotic peak occurred at the SCM $\left(2.76 \times 10^{3}\right.$ cells ml$\left.^{-1}\right)$.

Fig. $4 \mathrm{C}$ shows the results of the rbcL mRNA extraction and hybridization studies. As with Stn 4, the highest level of Form IA $r b c L$ mRNA occurred in the surface water, but this was only approximately $2.8 \%$ of the signal observed in the surface waters of Stn 4 . A second subsurface peak occurred at $50 \mathrm{~m}$ depth, coin- 

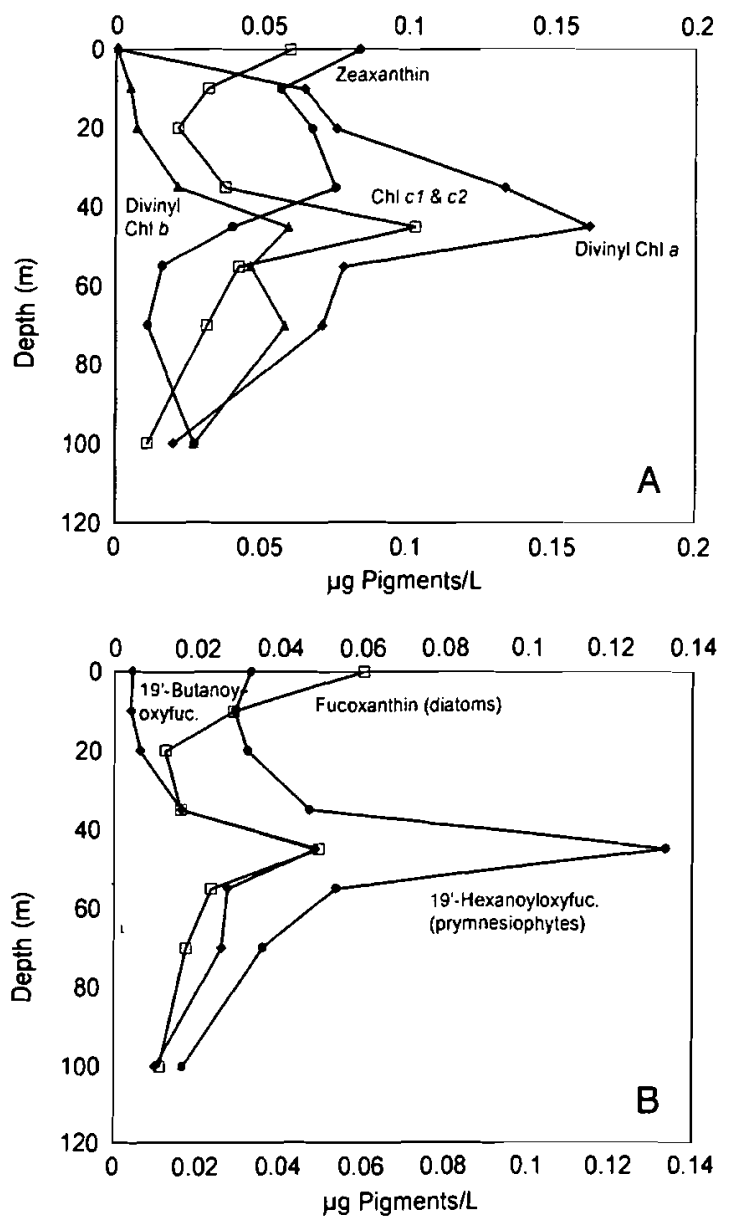

Fig. 3. Pigment data for Stn 4, including divinyl chlorophylls, chl $c 1$ and $c 2$, and (A) zeaxanthin, and (B) fucoxanthins

cident with the Prochlorococcus peak in cell abundance. There were no detectable levels of Form IB or Form ID rbcL mRNA at any depth.

Fig. 5A,B shows pigment data for Stn 7. As with Stn 4, zeaxanthin or the diagnostic cyanobacterial pigment was greatest in the surface water, while a secondary peak was found at $50 \mathrm{~m}$. Divinyl chl a had a peak at $70 \mathrm{~m}$ while divinyl chl $b$ had peaks at 70 and $90 \mathrm{~m}$, which overlapped or were slightly below the Prochlorococcus peak as determined by flow cytometry. We interpret this to mean that the deeper portion of the Prochlorococcus population (those occurring at 70 and $83 \mathrm{~m}$ ) had more cellular pigment content than those at $60 \mathrm{~m}$. Chl $c 1$ and $c 2$, the signature pigments of chromophytic picoeucaryotes, were maximal at the SCM $(83 \mathrm{~m})$, which coincided with the picoeucaryote peak as determined by flow cytometry. The signature pigments for prymnesiophytes and pelagophytes (19'hexanoyl-oxyfucoxanthin, and 19'-butanoyloxyfucoxanthin, respectively) all were maximal at the SCM, as found for Stn 4 .

\section{DISCUSSION}

A high abundance of Form IA $r b c L$ transcripts were found associated with a low salinity/high chl surface feature in the eastern third of the Gulf of Mexico. This is the first report of Form IA $r b c L$ transcripts or DNA in general in surface waters. We have previously reported Form IB $r b c L$ transcripts in the surface and middepth water off Bermuda, that closely followed the
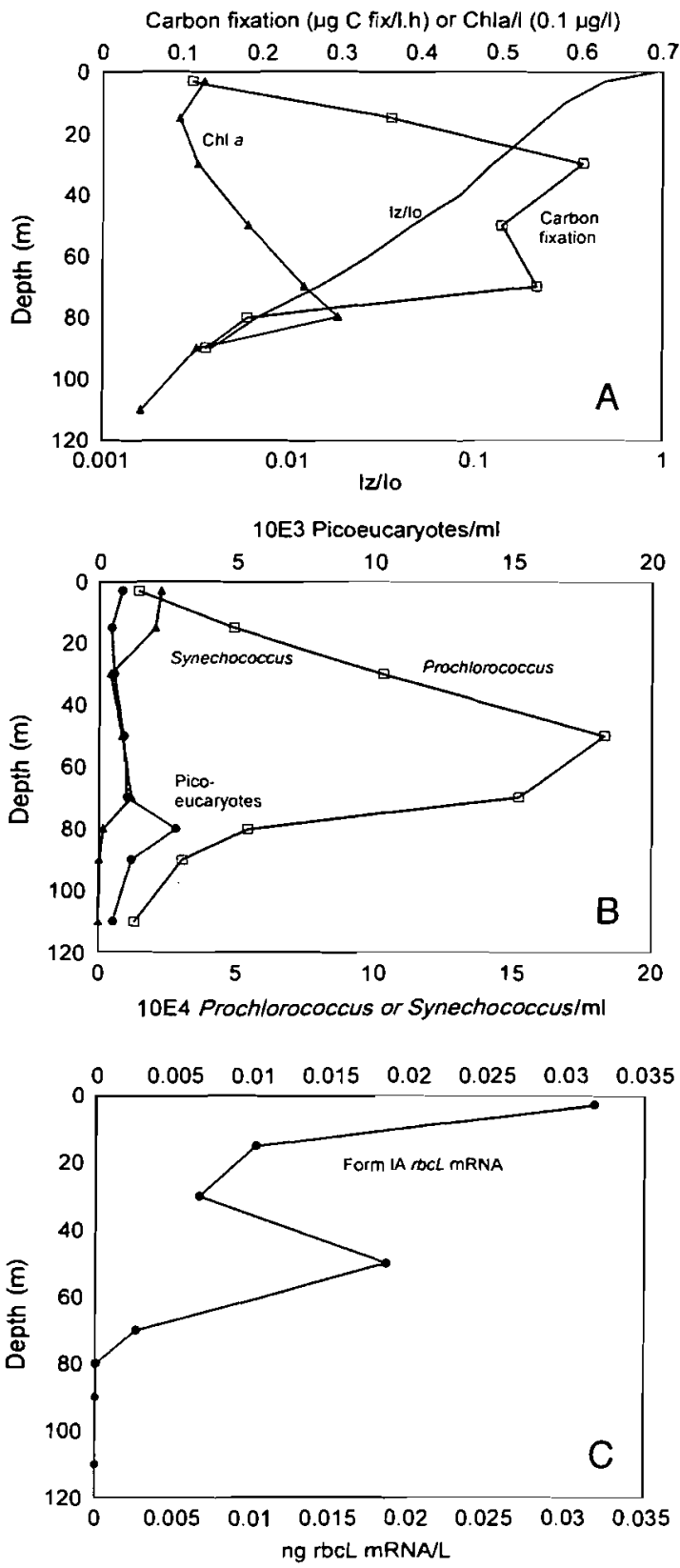

Fig. 4. (A) Relative light intensity (Iz/lo, -), photosynthetic carbon fixation ( $(0)$, and chl $a(\Delta)$ as a function of depth at Stn 7. (B) Flow cytometry data for the vertical profile at Stn 7. including Prochlorococcus (ㅁ), Synechococcus (४), and picoeucaryote $(\bullet)$ cell counts. (C) Form IA $r b c L$ mRNA at Stn 7 

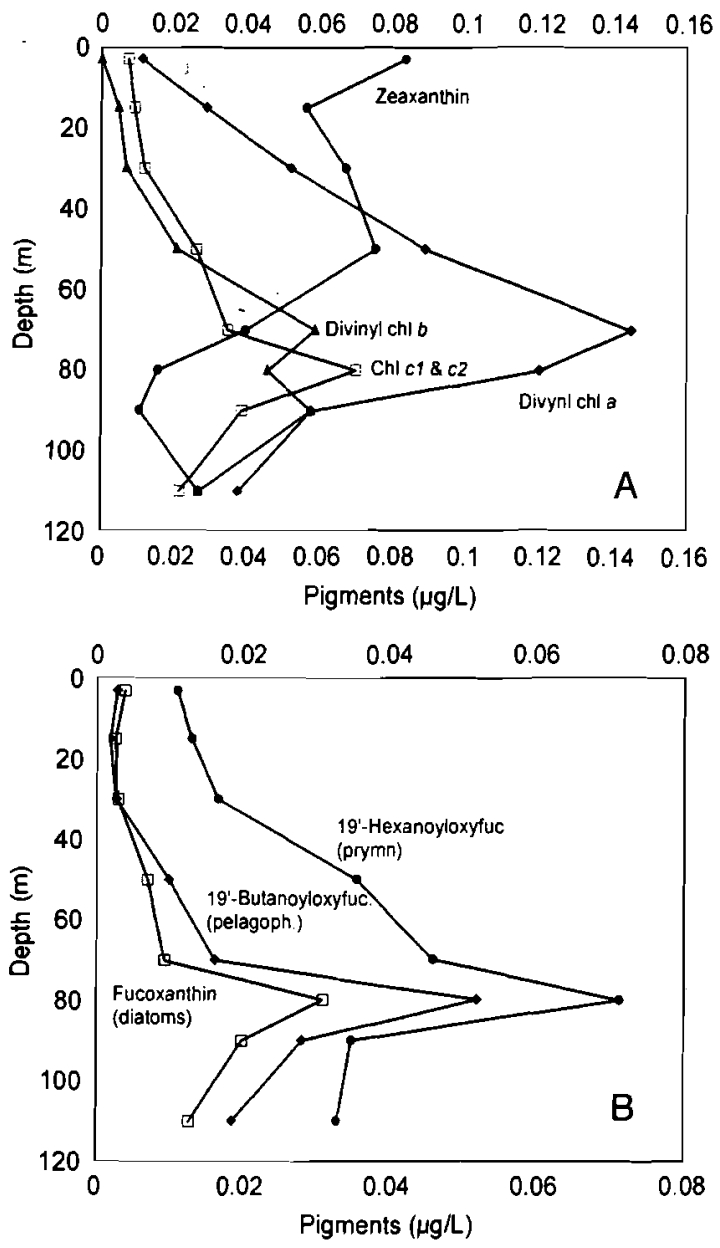

Fig. 5. Results of HPLC pigment analysis of Stn 7, including (A) divinyl chlorophylls, chl $c 1$ and $c 2$, and zeaxanthin and (B) fucoxanthin and derivatives

Synechococcus cell abundance maxima (Paul et al. 1999). Also, Form ID transcripts were most abundant at the SCM, coinciding with 'red fluorescent cell counts', presumably picoeucaryotes.

In the present study, the Form IA $r b c L$ coincided with a peak in Synechococcus abundance and the highest rates of carbon fixation at Stn 4. Synechococcus WH7803 has been shown to contain a Form IA RuBisCO (Watson \& Tabita 1996), as has Prochlorococcus GP2 (Shimada et al. 1995). These $r b c L$ genes are divergent from other Synechococcus and Prochlorococcus $r b c L$ sequences which are Form IB and more closely related to higher plants. It is thought that the Form IA $r b c L$ in Synechococcus WH7803 is the result of a lateral transfer event, potentially from a $\beta / \gamma$ purple bacterium (chemoautotroph or anoxygenic phototroph; Watson \& Tabita 1996). The importance of this form of RuBisCO in the ocean has not been previously recognized. The following paper indicates that sequences obtained from these waters were most closely related to Pro- chlorococcus GP2 and Synechococcus WH7803 and not other $\beta / \gamma$ purple bacteria.

A second peak in Synechococcus abundance occurred at $20 \mathrm{~m}$ at $\operatorname{Stn} 4$; yet little Form IA mRNA was found. This population may have been a population distinct from that found in the upper $10 \mathrm{~m}$, as it occurred in higher salinity water, not influenced by the plume. This population possessed less than $20 \%$ of the carbon fixation rate of the surface plume population. It may be that transcript degradation had already occurred in this population, while RuBisCO enzyme activity was still intact, enabling carbon fixation.

Although Prochlorococcus was the most numerically abundant picoplankter at both stations throughout the water column, there were no detectable Prochlorococcus cells in the surface waters of Stn 4 . This may have been caused by extremely low fluorescence of the surface populations of Prochlorococcus, preventing their detection by flow cytometry. However, divinyl chls were undetectable in the surface as well. If cellular pigment content was extremely low (as might be the case with surface populations), then it is possible that there was a surface Prochlorococcus population that was undetected by either pigment analysis or flow cytometry. In this case, given the low salinity plume, it appears that Synechococcus replaced Prochlorococcus in these surface waters.

The cellular levels of Form IA $r b c L$ transcripts found in the surface waters of Stn $4(0.059 \mathrm{fg}$ per Synechococcus cell) are slightly lower than those found by us at other sites (0.075 to $0.184 \mathrm{fg} \mathrm{cell}^{-1}$; Pichard et al. 1996). However, the latter data are for Form IB transcripts, and other organisms besides Synechococcus probably contributed to the hybridization signal.

The low salinity/high chl surface feature or plume has been observed previously, (Gilbes et al. 1996), and has been detected by Coastal Zone Color Scanner (CZCS) satellite imagery (Frank Muller Karger pers. comm.). At the time of sampling, there was no color satellite imagery available. Prior studies have termed a similar feature the 'Green River' for a low salinity plume extending out of Mobile Bay or Appalachicola Bay down the Eastern Gulf of Mexico/west Florida Shelf as far south as the Dry Tortugas (Gilbes et al. 1996). This feature is believed to be moved along in part by the Loop Current (Gilbes et al. 1996). It is not known if the Synechococcus cells found in this feature were oceanic species that bloomed in this nutrient rich coastal water or if this was a bloom of a coastal Synechococcus strain overlying oligotrophic Gulf of Mexico water.

The dominance of Prochlorococcus and the vertical separation of the 3 major picoplankton components (Synechococcus, Prochlorococcus, and picoeucaryotes) has been observed by others (Campbell et al. 1997). 
We found the Synechococcus to be bimodally distributed, with a surface population and a $50 \mathrm{~m}$ population (i.e. Stn 7). Below this was the Prochlorococcus cell abundance maximum, followed by the picoeucaryotes at the SCM. In the North Pacific, picoeucaryotes were found to comprise the SCM, and were abundant when nitrate was abundant. Prochlorococcus was found to be abundant when the nitrate was $<0.1 \mathrm{nM}$ (Blanchot \& Rodier 1996). Similarly, Landry et al. (1996) found Prochlorococcus and heterotrophic bacteria in the surface waters of the tropical Pacific, with Synechococcus and picoeucaryotes more abundant at depth. Analysis of a large data set suggests that Synechococcus, in most cases, is maximum in the upper portion of the water column (Partensky et al. 1999).

Chromophytic pigment analysis by HPLC indicated the presence of diatoms and other chromophytes (fucoxanthin and chl $c 1$ and $c 2$ ) at the SCM of both stations and in the surface waters of Stn 4 . The latter may have been the result of a coastal species entrained in the coastal plume encountered. Other chromophytic pigment signatures in our study included those of pelagophytes and prymnesiophytes, both occurring at the SCM. Prymnesiophytes have been shown to be important in primary production in the northern Mediterranean (Bustillos-Guzman et al. 1995, Barlow et al. 1997), in the equatorial Pacific, in the polar fronts of the Antarctic (Peeken 1997) and the northeast Atlantic (Mejanelle et al. 1995). Unlike diatoms, prymnesiophyte production is often balanced by microzooplankton grazing (Verity et al. 1996, Latasa et al. 1997).

Despite the abundance of the chromophytic forms at the SCM and associated carbon fixation, there was no chromophytic $r b c L$ mRNA measured. We have previously found Form 1D $r b c L$ mRNA at the SCM off Bermuda and in the Gulf of Mexico (Pichard et al. 1997b, Paul et al. 1999). We suspect that the lack of Form ID rbcL mRNA may have been caused by the time of sampling. We sampled between $07: 00$ and 10:00 $\mathrm{h}$ at both Stns 4 and 7. We have previously found a temporal separation between the Form IB and Form ID $r b c L$ mRNAs, with the latter produced between 12:00 and 19:00 $\mathrm{h}$. The chromophytic $r b c L$ regulation is apparently not controlled by transcription, but by post transcriptional/translational events (Paul et al. 1999). We have found a temporal shift in $r b c L$ transcription in cultures of the Prymnesiophyte Pavlova gyrans when compared to Synechococcus PCC7002 (J.B.K. \& J.H.P. unpubl. obs.). Alternatively, the lack of Form ID $r b c L$ mRNA at these stations could have been caused by another form of $r b c L$ yet to be described.

Acknowledgements. This work was supported by grants from the US Department of Energy to J.H.P. and a fellowship from the Austrian Science Fund to A.A.

\section{LITERATURE CITED}

Barlow RG, Mantoura RFC, Cummings DG, Fileman TW (1997) Pigment chemotaxonomic distributions of phytoplankton during summer in the western Mediterranean. Deep-Sea Res 44:833-850

Blanchot J, Rodier M (1996) Picophytoplankton abundance and biomass in the western Tropical Pacific Ocean during the 1992 El Nino year: results from flow cytometry. DeepSea Res 43:877-896

Bustillos-Guzman J, Claustre H, Marty JC (1995) Specific phytoplankton signatures and their relationship to hydrographic conditions in the coastal northwestern Mediterranean Sea. Mar Ecol Prog Ser 124:247-258

Campbell L, Liu H, Nolla HA, Vaulot D (1997) Annual variability of phytoplankton and bacteria in the subtropical North Pacific Ocean at Station ALOHA during the 1991-1994 ENSO event. Deep-Sea Res 44:167-192

Chisholm SW, Olson RJ, Zettler ER, Goericke R, Waterbury JB, Welschmeyer NA (1988) A novel free-living prochlorophyte abundant in the oceanic euphotic zone. Nature 334 : 340-343

Chisholm SW, Frankel SL, Goericke R, Olsen RJ, Palenik B, Waterbury JB, West-Johnsrud L, Zettler ER (1992) Prochlorococcus marinus nov. gen. sp.: an oxyphototrophic marine prokaryote containing divinyl chlorophyll $a$ and $b$. Arch Microbiol 157:297-300

DeLong EF (1992) Archaea in coastal marine environments. Proc Natl Acad Sci USA 89:5685-5689

Douglas SE, Durnford DG, Morden CW (1990) Nucleotide sequence of the gene for the large subunit of ribulose-1,5bisphosphate carboxylase/oxygenase from Cryptomonas $\Phi$. J Phycol 26:500-508

Ferris MJ, Palenik B (1998) Niche adaptation in ocean cyanobacteria. Nature 396:226-228

Fuhrman JA, McCallum K, Davis AA (1992) Novel major archaebacterial group from marine plankton. Nature 356 : 148-149

Fuhrman JA, McCallum K, Davis AA (1993) Phylogenetic diversity of subsurface marine microbial communities from the Atlantic and Pacific Oceans. Appl Environ Microbiol 59:1294-1302

Gilbes F, Tomas C, Walsh JJ, Muller-Karger FE (1996) An episodic chlorophyll plume on the West Florida Shelf. Con Shelf Res 16:1201-1224

Giovanonni SJ, Britschgi TB, Moyer CL, Field KG (1990) Genetic diversity in Sargasso Sea bacterioplankton. Nature 344:60-63

Holm-Hansen O, Riemann B (1978) Chlorophyll a determination: improvements in methodology. Oikos 30:438-447

Hwang SR, Tabita FR (1991) Cotranscription, deduced primary structure, and expression of the chloroplast-encoded $r b c L$ and $r b c S$ genes of the marine diatom Cylindrotheca sp. N1. J Biol Chem 266:6271-6279

Landry MR, Kirshtein J, Constantinou J (1996) Abundances and distributions of picoplankton populations in the Central Equatorial Pacific from $12^{\circ} \mathrm{N}$ to $12^{\circ} \mathrm{S}, 140^{\circ} \mathrm{W}$. DeepSea Res 43:871-890

Latasa M, Landry MR, Schlueter L, Bidigare RR (1997) Pigment-specific growth and grazing rates of phytoplankton in the central equatorial Pacific. Limnol Oceanogr 42: 289-298

Mejanelle L, Laureillard J, Fillaux J, Saliot A, Lambert C (1995) Winter distribution of algal pigments in small and large-size particles in the northeastern Atlantic. Deep-Sea Res 42:117-133

Millie DR, Paerl HW, Hurley JP (1993) Microalgal pigment 
assessments using high-performance liquid chromatography: a synopsis of organismal and ecological applications. Can J Fish Aquat Sci 50:2513-2527

Moore LR, Rocap G, Chisholm SE (1998) Physiology and molecular phylogeny of coexisting Prochlorococcus ecotypes. Nature 393:464-467

Morse O, Salois P, Markovic P, Hastinas JW (1995) A nuclearencoded Form Il RubisCO in dinoflagellates. Science 268: 1622-1624

Newman SM, Cattolico RA (1990) Ribulose bisphosphate carboxylase in algae: synthesis, enzymology and evolution. Photosynth Res 26:69-85

Partensky F, Hess WR, Vaulot D (1999) Prochlorococcus, a marine photosynthetic prokaryote of global significance. Microbiol Mol Biol Rev 63:106-127

Paul JH, Pichard SL, Kang JB, Watson GMF, Tabita FR (1999) Evidence for a clade-specific temporal and spatial separation in ribulose bisphosphate carboxylase gene expression in phytoplankton populations off Cape Hatteras and Bermuda. Limnol Oceanogr 44:12-23

Peeken I (1997) Photosynthetic pigment fingerprints as indicators of phytoplankton biomass and development in different water masses of the Southern Ocean during austral spring. Deep-Sea Res 44:261-282

Pichard SL, Frischer ME, Paul JH (1993) Ribulose bisphosphate carboxylase gene expression in subtropical marine phytoplankton populations. Mar Ecol Prog Ser 101:55-65

Pichard SL, Campbell L, Carder K, Kang JB, Patch J, Tabita FR, Paul JH (1997a) Analysis of ribulose bisphosphate carboxylase gene expression in natural phytoplankton populations by group-specific gene probing. Mar Ecol Prog Ser 149:239-253

Pichard SL, Campbell L, Paul JH (1997b) Diversity of ribulose bisphosphate carboxylase oxygenase Form I gene $(r b c L)$ in natural phytoplankton communities. Appl Environ Microbiol 63:3600-3606

Raven JA (1995) Inorganic carbon assimilation by marine biota. J Exp Mar Biol Ecol 203:39-47

Scanlan DJ, Hess WR, Partensky F, Newman J, Vaulot D (1996) High degree of genetic variation in Prochlorococcus (Prochlorophyta) revealed by RFLP analysis. Eur J Phycol 31:1-9

Stockner JG (1988) Phototrophic picoplankton: an overview from marine and freshwater ecosystems. Limnol Oceanogr 33:765-775

Editorial responsibility: Jed Fuhrman (Contributing Editor), Los Angeles, California, USA
Shimada A, Kanai S, Maruyama T (1995) Partial sequence of Ribulose-1,5-bisphosphate carboxylase/oxygenase and phylogeny of Prochloron and Prochlorococcus (Prochlorales). J Mol Evol 40:671-677

Tabita FR (1988) Molecular and cellular regulation of autotrophic carbon dioxide fixation in microorganisms. Microbiol Rev 52:155-189

Toledo G, Palenik B (1997) Synechococcus diversity in the California Current as seen by RNA polymerase (rpoC1) gene sequences of isolated strains. Appl Environ Microbiol 63:4298-4303

Urbach E, Chisholm SW (1998) Genetic diversity in Prochlorococcus populations flow cytometrically sorted from the Sargasso Sea and Gulf Stream. L.imnol Oceanogr 43: $1615-1630$

Urbach E, Scanlan DJ, Distel DL, Waterbury JB, Chisholm SW (1998) Rapid diversification of marine picophytoplankton with dissimilar light-harvesting structures inferred from sequences of Prochlorococcus and Synechococcus (Cyanobacteria). J Mol Evol 46:188-201

Valentin K, Zetsche K (1990) Structure of the Rubisco operon from the unicellular red alga Cyanidium caldarium: evidence for a polyphyletic origin of the plastids. Mol Gen Genet 222:425-430

Valuot D (1989) CYTOPC: processing software for flow cytometric data. Signal Noise $2: 8$

Verity PG, Stoecker DK, Sieracki ME, Nelson JR (1996) Microzooplankton grazing of primary production at $140^{\circ} \mathrm{W}$ in the Equatorial Pacific. Deep-Sea Res 43:1227-1256

Waterbury JB, Rippka R (1989) Subsection 1. Order Chroococcales Wettstein 1924, emend. Rippka et al. 1979. In: Staley JT, Bryan MP, Pfennig N, Holt JG (eds) Bergey's manual of systematic bacteriology, Vol 3. Williams and Wilkins, Baltimore, p 1728-1756

Watson GMF, Tabita FR (1996) Regulation, unique gene organization and unusual primary structure of carbon fixation genes from a marine phycoerythrin-containing cyanobacterium. Plant Mol Biol 32:1103-1106

Watson GMF, Tabita FR (1997) Microbial ribulose 1,5-bisphosphate carboxylase/oxygenase: a molecule for phylogenetic and enzymological investigation. FEMS Microbiol Lett 146: $13-22$

Watson GMF, Tabita FR (1999) Unusual ribulose 1,5-bisphosphate carboxylase/oxygenase of anoxic Archaea. J Bacteriol 181:1569-1575

Submitted: August 27, 1999; Accepted: November 11, 1999 Proofs received from author(s): May 9, 2000 